\title{
p53 expression in hepatocellular carcinoma in a population in Singapore with endemic hepatitis $B$ virus infection
}

\section{Department of Pathology, National University Hospital, Lower Kent Ridge \\ Road, Singapore 0511, Republic of Singapore A Wee \\ M Teh \\ G C Raju}

Correspondence to: Associate Professor A Wee. Accepted for publication 19 July 1994

\author{
A Wee, M Teh, G C Raju
}

\begin{abstract}
Aims-To study the expression and clinical significance (if any) of 53 protein in hepatocellular carcinomas (HCC) arising in a population with endemic hepatitis $B$ virus (HBV) infection.

Methods-Immunohistochemical staining was performed on formalin fixed, paraffin wax embedded histological sections of 46 HCC cases using an antihuman p 53 monoclonal antibody; serial sections were also stained for hepatitis $B$ surface antigen (HBsAg), hepatitis B core antigen (HBcAg) and alpha fetoprotein (AFP). Nuclear p53 staining was assessed according to intensity (absent, weak or strong) and extent (<5\%, 6-25\%, 26-50\%, and $>50 \%$ ) of positive cells. Tissue HBsAg, HBcAg and AFP were recorded as absent or present.

Results-The p53 protein was expressed in $35 \%$ (16 of 46) of HCCs; the positive rate in grade III/IV tumours (13 of 31; $42 \%$ ) was higher than in grade I/II tumours (three of $15 ; 20 \%$ ) but this was not statistically significant. HBsAg positive tumours showed almost the same proportion of p53 staining (11 of 29; 38\%) as HBsAg negative ones (five of $17 ; 29 \%$ ).

Conclusions-The p53 protein was expressed in $35 \%$ of HCC cases. There was no statistically significant correlation between HBV infection and p53 protein expression. Similarly, there was no definite correlation between p53 positivity and tumour size, histological grade or vascular invasion.
\end{abstract}

(F Clin Pathol 1995;48:236-238)

Keywords: Hepatocellular carcinoma, immunohistochemistry, $\mathrm{p} 53$ protein.

Mutation of the p53 tumour suppressor gene represents the most common molecular change in human cancer ${ }^{1-9}$ and has been identified in hepatocellular carcinomas (HCC). The frequency rates, however, show geographical variation. In HCC prevalent countries such as Mozambique and the Qidong area in China, regions exposed to high aflatoxin concentrations, the rates of p53 mutation have been reported to be as high as 59 and $50 \%$, respectively. ${ }^{10-13}$ At the other end of the spectrum, these high rates are rarely found in HCC cases from countries such as Japan (19\%) and in whites resident in the United Kingdom $(20 \%){ }^{14-16}$
Singapore, with a predominantly Chinese population, has a high incidence of HCC. ${ }^{17}$ It also has a significant hepatitis B virus (HBV) carrier population with most cases of HCC arising in patients with $\mathrm{HBV}$ infection. ${ }^{18}$ Integration of HBV DNA into the hepatocytic genome is frequently associated with the presence of HCC, with chromosome 17 being one of the targets. ${ }^{19}$ In some cases the viral insert was mapped to chromosome $17 p$ near the $p 53$ gene chromosomal location, ${ }^{20}$ raising the possibility of a link between p53 gene mutation and HBV induced HCC. There have been some recent data showing that the prevalence of $\mathrm{p} 53$ positive HCC was significantly higher in patients with serological markers of hepatitis B or C viral infection than in those without. ${ }^{21}$

With this in mind, we decided to analyse immunohistochemically the frequency and clinical significance (if any) of p53 protein expression in HCC occurring in Singapore where $\mathrm{HBV}$ infection is endemic.

\section{Methods}

Hepatocellular carcinoma liver resection specimens taken between January 1988 and March 1994 were retrieved from the archives of the Department of Pathology, National University Hospital, Singapore. This retrospective review yielded 46 cases, all of whom were of Asian origin (41 Chinese, three Malay and two Indonesian).

All of the HCC specimens had been fixed in $10 \%$ buffered formalin and routinely processed. Paraffin wax embedded histological sections stained with haematoxylin and eosin were evaluated. The tumour size was noted. HCC specimens were graded from I to IV according to Edmondson and Steiner's classification. ${ }^{22}$ Vascular invasion was recorded. Adjacent nontumorous liver parenchyma was examined for the presence of cirrhosis.

p53 protein immunostaining was performed using a Streptavidin biotin immunoperoxidase method. Deparaffinised $4 \mu \mathrm{m}$ sections were treated with 3\% hydrogen peroxide for $10 \mathrm{~min}$ utes to block endogenous peroxidase. The sections were then incubated with $5 \%$ bovine serum albumin (BSA) in TRIS-buffered saline (TBS) for 30 minutes to eliminate any non-specific staining. Excess BSA was drained from the slides before the addition of an antihuman p 53 monoclonal antibody (DO-7; Dako, Glostrup, Denmark; M7001) at an optimal dilution of 1 in 50 in $0.1 \% \mathrm{BSA}$ and incubated overnight at $4{ }^{\circ} \mathrm{C}$. The tissue sections were subsequently washed with TBS and incubated with biotinylated 
Correlation between clinical and histological features and p53 status in hepatocellular carcinoma

\begin{tabular}{|c|c|c|c|}
\hline Characteristics & Total & p53 positive & p53 negative \\
\hline $\begin{array}{l}\text { Number of patients } \\
\text { Sex (M:F) } \\
\text { Age (years) }\end{array}$ & $\begin{array}{l}46 \\
37: 9 \\
30-76 \\
(\text { mean, 54.3) }\end{array}$ & $\begin{array}{l}16 \\
13: 3 \\
30-76 \\
(\text { mean, 54.6) }\end{array}$ & $\begin{array}{l}30 \\
24: 6 \\
34-76 \\
(\text { mean, 54.2) }\end{array}$ \\
\hline \multicolumn{4}{|c|}{ (mean, $34 \cdot 6)$} \\
\hline Chinese & 41 & 15 & 26 \\
\hline Others & 5 & 1 & 4 \\
\hline HBV infection & 29 & 11 & 18 \\
\hline AFP elevation & 21 & 11 & 10 \\
\hline \multicolumn{4}{|l|}{ Tumour } \\
\hline size of tumour $(\mathrm{cm})$ & $1 \cdot 5-14 \cdot 5$ & $\begin{array}{l}2-13 \\
\text { (mean, } 8 \cdot 1)\end{array}$ & $\begin{array}{l}1 \cdot 5-14 \cdot 5 \\
(\text { mean, } 7 \cdot 6)\end{array}$ \\
\hline \multicolumn{4}{|l|}{ Edmondson's grade } \\
\hline I & 7 & 1 & 6 \\
\hline II & 8 & 2 & 6 \\
\hline III & 24 & 9 & 15 \\
\hline IV & 7 & 4 & 3 \\
\hline vascular invasion & 38 & 16 & 22 \\
\hline HBsAg positive & 6 & 1 & 5 \\
\hline HBcAg positive & 1 & 0 & 1 \\
\hline \multicolumn{4}{|l|}{ Non-tumourous liver } \\
\hline cirrhotic & 19 & 8 & 11 \\
\hline HBsAg positive & 29 & 11 & 18 \\
\hline HBcAg positive & 4 & 2 & 2 \\
\hline
\end{tabular}

rabbit antimouse immunoglobulin (Dako, E354), diluted 1 in 200 in $0.1 \%$ BSA for one hour at room temperature. After washing with TBS, the sections were incubated with peroxidase conjugated Streptavidin (Dako, K9000), diluted 1 in 400 in TBS (pH 7.6), for one hour at room temperature. Finally, the sections were developed in diaminobenzedine in hydrogen peroxide substrate with $50 \mathrm{mg}$ of imidazole (Sigma, St Louis, Missouri, USA; 1-0250) for 10 minutes. The sections were counterstained with Gill's haematoxylin. Sections in which the primary antibody was replaced with non-immune rabbit serum served as negative controls. A p53 positive gall bladder carcinoma served as a positive control. On analysis of p53 immunoreactivity only nuclear staining was regarded as specific. The intensity of staining was graded as either absent $(0)$, weak $(+)$ or strong $(++)$. The extent of staining was semiquantitatively evaluated and categorised as

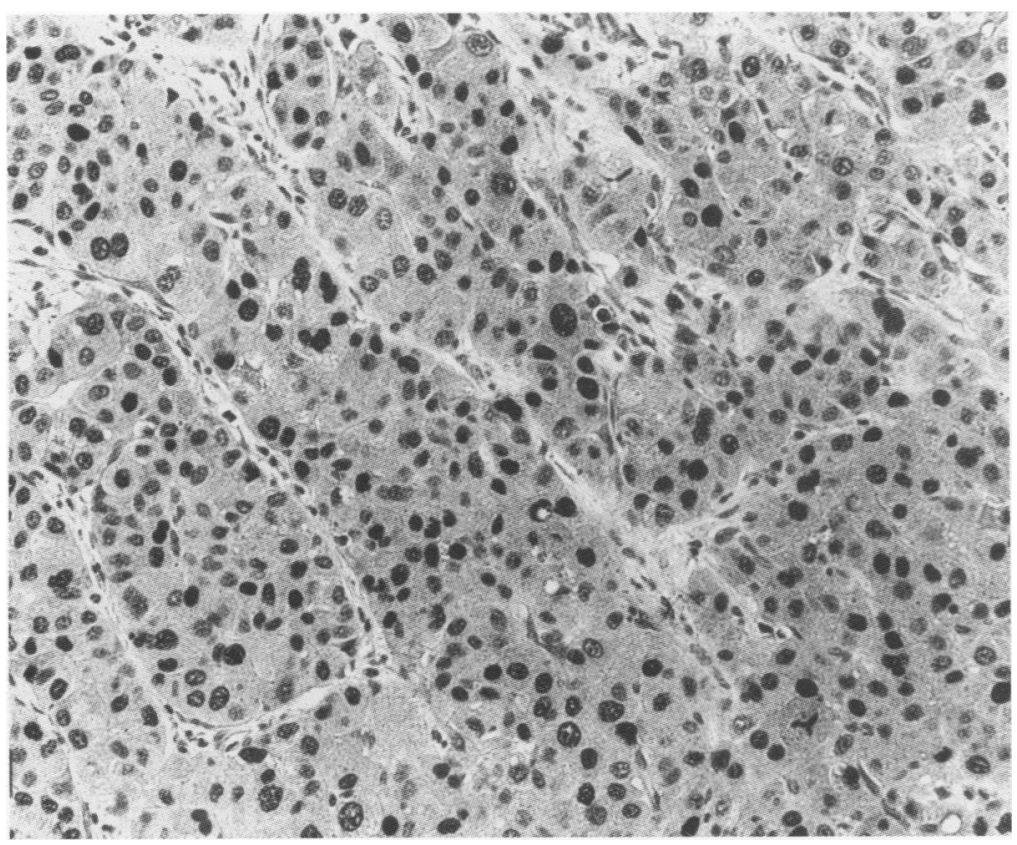

$A$ hepatocellular carcinoma showing extensive p53 staining of the nuclei (immunoperoxidase; $\times 50$ ).
$<5 \%, 6-25 \%, 26-50 \%$, and $>50 \%$ of positive cells.

Serial sections of the tumour and non-tumorous tissue were also stained for hepatitis $B$ surface antigen (HBsAg) (Calbiochem, San Diego, California, USA), hepatitis B core antigen (HBcAg) (Dako) and alpha fetoprotein (AFP) (Dako) using Streptavidin biotin immunoperoxidase methods. $\mathrm{HBsAg}, \mathrm{HBcAg}$ and AFP were recorded as absent or present. Categorical data were assessed using the $\chi^{2}$ test.

\section{Results}

p53 protein expression was detected in 16 $(35 \%)$ of the $46 \mathrm{HCCs}$ analysed (table). The average size of $\mathrm{p} 53$ positive tumours was $8 \cdot 1 \mathrm{~cm}$ compared with $7.6 \mathrm{~cm}$ for the negative lesions. Vascular invasion was evident in 38 (83\%) cases, 16 of which expressed p53 protein. Cirrhosis was documented in $19(41 \%)$ patients; of these, eight had p53 expression in tumour cells. AFP was detected in the tumour cells of $21(46 \%)$ patients, 11 of whom had $\mathrm{p} 53$ positive lesions. A higher proportion of grade III/IV tumours (13 of $31 ; 42 \%$ ) than grade I/II tumours (three of $15 ; 20 \%$ ) were p53 positive $(p<0 \cdot 26)$. Considering only p53 tumours showing extensive staining - that is, at least more than $25 \%$ of the tumour cells, p53 was expressed in five of $23(22 \%)$ grade III/IV tumours compared with one of $13(8 \%)$ grade I/ II tumours (figure).

HBsAg was detected in 29 (63\%) cases; staining was also present in the tumour cells in six of these. HBcAg was detected in four HBsAg carriers; one showed staining within tumour cells and this case also contained malignant HBsAg positive cells. Overall, no difference was noted in p53 positivity between the HBV positive tumours (11 of $29 ; 38 \%$ ) when compared with HBV negative ones (five of 17; $29 \%)(\mathrm{p}<0 \cdot 80)$. Furthermore, p53 expression was absent in those cases where HBsAg (five of six) and HBcAg (one patient) was demonstrated in the malignant cells.

\section{Discussion}

Abnormalities in the structure and expression of the p53 tumour suppressor gene occur frequently in HCC cell lines. ${ }^{8}$ So far, the clustering of p53 mutations at codon 249 seems to be HCC specific. In fact, $G$ to $T$ mutations at codon 249 have been identified at comparable frequency in HCC from the Qidong area of China, a region with high exposure to aflatoxins. ${ }^{13}$ However, reports from other parts of the world show that $\mathrm{p} 53$ mutation rates in HCC vary from low aflatoxin, low HCC incidence populations to high aflatoxin, high HCC incidence populations. ${ }^{12-16}$ These data indicate that there is a possible geographic variation in the cause and pathogenesis of HCC and that HCC may not be a homogeneous group of tumours as far as genetic mechanisms are concerned.

Apart from aflatoxins, $\mathrm{HBV}$ infection is also a known risk factor for HCC. In fact, integration of HBV DNA into the hepatocytic genome is a frequent event associated with 
hepatocarcinogenesis; viral integration into the chromosome occurs close to the p53 gene locus. ${ }^{1920}$ Therefore, a link between p53 gene mutation and HBV induced HCC is possible. ${ }^{21}$

Singapore has a population with endemic HBV infection and a high prevalence of HCC. ${ }^{1718}$ In our analysis $35 \%$ (16 of 46 ) of the patients with HCC examined were p53 positive on immunohistochemistry. This represents an intermediate rate between populations with high and low incidence of HCC. ${ }^{10-162123}$ We found a higher proportion of p53 protein expression in grade III/IV tumours but the numbers were too small for statistical analysis. There was no definite correlation with tumour size, cirrhosis or AFP status.

We were unable to demonstrate a positive correlation between $\mathrm{HBV}$ infection and p53 protein expression in HCC $(p<0 \cdot 80)$. Furthermore, we noted that of the six cases with $\mathrm{HBsAg}$ positive and the single case with $\mathrm{HBcAg}$ positive malignant cells, almost all developed $\mathrm{HCC}$ in the absence of $\mathrm{p} 53$ protein expression. These findings are at variance with a recent report showing that the prevalence of $\mathrm{p} 53$ positive HCC was significantly higher in patients with serological markers of $\mathrm{HBV}$ infection than in those without. ${ }^{21}$ However, we must emphasise that we were indirectly examining p53 gene mutations through immunohistochemical detection of the more stable mutant p53 protein. Wynford-Thomas has pointed out the range of circumstances in which detectable p53 expression might not correlate with the presence of mutation of the p53 gene giving false positive or false negative results. ${ }^{24}$ In viral induced carcinogenesis the viral protein may actually target the p53 protein to more rapid catabolism, as in the case with the human papilloma virus. ${ }^{25}$ It would appear from the results of our study that either p 53 mutations in HCC are not correlated with HBV infection or that viral infection acts by negating the increase in the half-life of the mutated p53 protein.

The authors wish to thank Mr TC Tan for photography, CK Ow for technical work and Mrs AT Mok for stenographic assistance.

1 Levine AJ, Momad J, Finlay CA. The p53 tumor suppressor gene. Nature 1991;351:453-6.

2 gene. Nature $1991 ; 351: 453-6$. normality in human cancer? $\mathcal{F}$ Clin Pathol 1990;162:5-6.
3 Han K, Kulesz-Martin MF. Altered expression of wild-type p53 tumor suppressor gene during murine epithelial cell p53

4 Eliyahu D, Michalovitz D, Oren M. Overproduction of p53 antigen makes established cells highly tumorigenic. Nature 1985;316:158-62.

5 Finlay CA, Hinds PW, Levine AJ. The p53 protooncogene can act as a suppressor of tranformation. Cell 1989;57: 1083-93.

6 Hollstein M, Sidransky D, Vogelstein B, Harris C. p53 mutations in human cancers. Science 1991;253:49-53.

7 Porter PL, Gown AM, Kramp SG, Coltrera MD. Widespread p53 overexpression in human malignant tumors. Am f Pathol 1992;140:145-53.

8 Soussi T, Legros Y, Lubin R, Ory K, Schlichtholz B. Multifactorial analysis of p53 alteration in human cancer: A review. Int $\mathcal{F}$ Cancer 1994;57:1-9.

9 Hall PA, Lane DP. p53 in tumour pathology: can we trust immunohistochemistry? - revisited! [editorial] $\mathcal{f}$ Pathol 1994;172:1-4.

10 Ozturk M. p53 mutation in hepatocellular carcinoma after aflatoxin exposure. Lancet 1991;338:1356-9.

11 Oda T, Tsuda H, Scarpa A, Sakamoto M, Hirohashi S. Mutation pattern of the p53 gene as a diagnostic marker for multiple hepatocellular carcinoma. Cancer Res 1992; 52:3674-8.

12 Bressac B, Kew M, Wands J, Ozturk M. Selective G to T mutations of $\mathrm{p} 53$ gene in hepatocellular carcinoma from mutations of p53 gene in hepatocellular carc
southern Africa. Nature 1991;350:429-31.

13 Hsu IC, Metcalf RA, Sun T, Welsh JA, Wang NJ, Harris CC. Mutational hotspot in the p53 gene in human hepaCC. Mutational hotspot in the p53 gene in hu
tocellular carcinomas. Nature 1991;350:427-8.

14 Murakami Y, Hayashi K, Hirohashi S, Sekiya T. Aberrations of tumor suppressor p53 and retinoblastoma genes in human hepatocellular carcinomas. Cancer Res 1991;51: $5520-5$

15 Challen C, Warren W, Guo K, Lunec J, Bassendine MF. p53: A frequent target for genetic abnormalities in human hepatocellular carcinomas (HCC) in Britain [abstract]? Hepatology 1991;14:94A.

16 Challen C, Lunec J, Warren W, Collier J, Bassendine MF. Analysis of the p53 tumor-suppressor gene in hepaAnalysis of the p53 tumor-suppressor gene in hepatocellular

17 World Health Organization: Trends in Cancer Incidence in Singapore, 1968-1982. Lee HP, Day NE, Shanmugaratnam $\mathrm{K}$, eds. Lyon: International Agency for Research on Cancer, 1988:85.

18 Oon CJ, Chan L, Chan SH, Goh CN, Gok KT, Lim GK, et al. Epidemiology of hepatitis B virus (HBV) infection in Singapore. In: Lam SK, Lai CL, Yeoh EK, eds. Viral hepatitis $B$ infection. Singapore World Scientific Publishing 1984:51-3.

19 Robinson WS, Klote L, Aoki N. Hepadnaviruses in cirrhotic liver and hepatocellular carcinoma. $\mathcal{F}$ Med Virol 1990;31: $18-32$.

20 Slagle BL, Zhou YZ, Butel JS. Hepatitis B virus integration event in human chromosome $17 \mathrm{p}$ near $\mathrm{p} 53$ gene identifies the region of the chromosome commonly deleted in virus the region of the chromosome commonly deleted in virus positive

21 Laurent-Puig P, Flejon J-F, Fabre M, Bedossa P, Belghiti J, Gayral F, et al. Overexpression of p53: A rare event in a large series of white patients with hepatocellular carcinoma. Hepatology 1992;16:1171-5.

22 Edmondson HA, Steiner PE. Primary carcinoma of the liver. A study of 100 cases among 48900 necropsies. Cancer 1954;7:462-503.

23 Collier JD, Carpenter M, Burt AD, Bassendine MF. Expression of mutant $\mathrm{p} 53$ protein in hepatocellular carpression of mutant p53 protein

24 Wynford-Thomas D. p53 in tumour pathology: can we trust immunocytochemistry? [editorial]. $\mathcal{F}$ Pathol 1992;166: 329-30.

25 Scheffner M, Werness BA, Huibregtse JM, Leving AJ, Howley PM. The E6 oncoprotein encoded by human papilloma virus type 16 and 18 promotes degradation of p53. Cell 1990;63:1129-36. 